DOI: $10.2478 / \mathrm{v} 10014-012-0006-3$

COBISS Code 1.01

Agrovoc descriptors: malus pumila, apples, lactuca sativa, lettuces, solanum tuberosum, potatoes, pesticides, residues, maximum residue limits, food safety, regulations, integrated pest management, integrated control, plant protection

Agris category code: $\mathrm{H} 10$

\title{
Pesticide residues in samples of apples, lettuce and potatoes from integrated pest management in Slovenia from 2005-2009
}

\author{
Helena BAŠA ČESNIK ${ }^{1}$, Špela VELIKONJA BOLTA ${ }^{1}$, Ana GREGORČIČ ${ }^{1}$
}

Received September 05, 2011; accepted Februay 29, 2012.

Delo je prispelo 05. septembra 2011, sprejeto 29. februarja 2012.

\begin{abstract}
In the period from 2005 to 2009225 samples of apples, lettuce and potatoes from Slovene producers included in integrated pest management (IPM) were analysed for plant protection product (PPP) residues. The samples were analysed for the presence of more than 200 different active compounds using four analytical methods. In $38.7 \%$ of apple samples residues were not detected, $58.6 \%$ of apple samples contained residues lower than or equal to Maximum Residue Levels (MRLs) while $2.7 \%$ of apple samples exceeded MRLs. In $84.6 \%$ of lettuce samples residues were not detected, $12.3 \%$ of lettuce samples contained residues lower than or equal to MRLs while $3.1 \%$ of lettuce samples exceeded MRLs. In $98.0 \%$ of potato samples residues were not detected, $2.0 \%$ of potato samples contained residues lower than or equal to MRLs and no potato samples exceeded MRLs. Multiple residues were found only in apples and lettuce. The trend observed during the years was the decrease of sample portion of samples containing multiple residues in apples from 2005 to 2008 . The most frequently found active substance in apples and lettuce was dithiocarbamates. In potato only phosalone was found.
\end{abstract}

Key words: apples, lettuce, potatoes, integrated pest management, plant protection product residues, GC/MS, LC/MS/MS

\section{IZVLEČEK}

\section{OSTANKI PESTICIDOV V VZORCIH JABOLK, SOLATE IN KROMPIRJA V INTEGRIRANI PRIDELAVI V SLOVENIJI V LETIH 2005-2009}

V obdobju od 2005 do 2009 smo na ostanke fitofarmacevtskih sredstev (FFS) analizirali 225 vzorcev jabolk, solate in krompirja slovenskih proizvajalcev vključenih $\mathrm{v}$ integrirano pridelavo (IP). Vse vzorce smo analizirali s štirimi analitskimi metodami na prisotnost več kot 200 različnih aktivnih spojin. V 38,7\% vzorcev jabolk ostankov nismo določili, 58,6\% vzorcev jabolk je vsebovalo ostanke manjše ali enake maksimalnim dovoljenim količinam ostankov (MRL) medtem ko je 2,7\% vzorcev jabolk preseglo MRL vrednosti. V $84.6 \%$ vzorcev solate ostankov nismo določili, $12,3 \%$ vzorcev solate je vsebovalo ostanke manjše ali enake MRL vrednostim medtem ko je 3,1\% vzorcev solate preseglo MRL vrednosti. V $98,0 \%$ vzorcev krompirja ostankov nismo določili, 2,0\% vzorcev krompirja je vsebovalo ostanke manjše ali enake MRL vrednostim in nobeden vzorec krompirja ni presegel MRL vrednosti. Ostanke dveh ali več aktivnih spojin smo določili le v jabolkih in solati. Trend, ki smo ga opazili tekom let je, da delež vzorcev, ki vsebujejo ostanke dveh ali več aktivnih spojin v jabolkih, pada od leta 2005 do 2008. Najpogosteje najdena aktivna snov $\mathrm{v}$ jabolkih in solati je ditiokarbamati. V krompirju smo določili le fosalon.

Ključne besede: jabolka, solata, krompir, integrirana pridelava, ostanki fitofarmacevtskih sredstev, GC/MS, LC/MS/MS

\footnotetext{
1 Agricultural Institute of Slovenia, Hacquetova ulica 17, SI-1000 Ljubljana, Slovenia, Ph.D.
} 


\section{INTRODUCTION}

The main objective of conventional farming is elimination of the pest with at least $90 \%$ effectiveness, while IPM aims to maintain a population level or balance below the tolerance threshold, intervening only when the population density exceeds an action treshold (Oliva et al., 1999). Unfortunately, conventional farming poses a negative impact on the environment, agriculture, and human health. PPP may kill pests, disease, and weed, but they also end up as residues on our food. The largest negative impact of conventional farming is its contamination of our freshwater supply, soil erosion and decreased soil fertility. PPP also enter the air and can be transported to other areas where no PPPs are used. The PPP use has a negative impact on natural predators, because they do not only kill the targeted pests but also other beneficial organisms. Regular application of PPP ends up breeding a stronger, more resistant community to PPPs (Kaul et al., 2009; Turgut et al., 2011; Vasileiadis et al., 2011)

Concerns about the negative effects of PPPs led to research and promotion of alternative crop production such as IPM.

IPM is a careful consideration of all available plant protection methods and subsequent integration of appropriate measures that discourage the development of populations of harmful organisms and keep the use of PPPs and other forms of intervention to levels that are economically and ecologically justified and reduce or minimise risks to human health and the environment (Vasileiadis et al., 2011). In other words, the IPM is a system that includes measures required for a good agricultural practice, for the safety and hygiene of workers, for the safety of products, for the full traceability of measurements and for the preservation of the environment (Danis et al., 2011).

In spite of that, IPM itself is not a guaranty that PPP residues will not be found in the environment. Also PPP residues used in IPM are found in water, soil and are transported to other areas. But with measures taken in IPM their content in water, soil and air will be better controlled and/or reduced to minimum required for food production than in conventional farming.

In Slovenia the PPPs allowed in IPM are yearly published in the Technical Guidelines for IPM in fruit, grape, vegetables and field crop growing. The main benefits are lower incidence and lower levels of PPP residues in agricultural products. To control this type of production surveillance monitoring is required. This is why Agricultural Institute of Slovenia determined PPP residues in apple, lettuce and potato of the Slovene producers included in IPM prior to the market in accordance to the Slovenian legislation (RS 2004a, 2004b, 2007a, 2007b, 2009).The samples were taken randomly in eight production areas in Slovenia: Celje, Koper, Kranj, Nova Gorica, Novo mesto, Murska Sobota, Maribor, and Ljubljana. Apples, lettuce and potatoes were chosen because they are the most frequently consumed agricultural products in Slovenia (the Slovene Food Basket has not yet been demarcated). The results are intended to:

- Determine the conformity with the legally prescribed MRLs

- Determine the conformity of the production with good agricultural practice

- Determine the sources and/or causes of residues found

For the monitoring purposes quick and reliable multiresidual methods which enable simultaneous determination of a wide spectrum of active substances are needed. Extraction is performed by ethylacetate (Berrada et al., 2006; Čajka and Hajšlová, 2004; Ferrer et al., 2005; Sharif et al., 2006), acetonitrile (method also known as QuEChERS method) (Lehotay, 2007; Maštovská et al., 2005) or acetone (Díez et al., 2006; Pizzutti et al., 2009; Stan and Linkerhägner, 1996). We used the multiresidual method in which extraction was performed with acetone, petroleumether and dichlorometane and determination with gas chromatograph coupled to mass spectrometer (GC-MS) (Baša Česnik and Gregorčič, 2003; Baša Česnik et al., 2006). The same extraction procedure was also used for another multiresidual method in which liquid chromatography was coupled to tandem mass spectrometry (LC/MS/MS) (Bossi et al., 2002; Ortelli et all., 2004; Lehotay et al., 2005). Single residue methods were also used for the determination of maneb group and benzimidazoles. Extraction of the maneb group (dithiocarbamates) was performed with isooctane and determination with GC-MS (Baša Česnik and Gregorčič, 2006). Benzimidazoles were extracted by acetone, petroleumether and dichloromethane and determined by LC with UV and fluorescent detector (van Zoonen, 1996). 


\section{MATERIALS AND METHODS}

From 2005 to 2009, 225 samples of apples, lettuce and potatoes from IPM were analysed. The sampling is presented in Table 1.

Table 1. Number of IPM samples of apple, lettuce and potato.

\begin{tabular}{|l|l|l|l|l|l|l|}
\hline & $\mathbf{2 0 0 5}$ & $\mathbf{2 0 0 6}$ & $\mathbf{2 0 0 7}$ & $\mathbf{2 0 0 8}$ & $\mathbf{2 0 0 9}$ & sum \\
\hline apples & 15 & 30 & 37 & 29 & $/$ & 111 \\
\hline lettuce & 12 & 12 & 17 & 12 & 12 & 65 \\
\hline potatoes & 3 & 12 & 6 & 8 & 20 & 49 \\
\hline
\end{tabular}

For the determination of PPP residues we used four different testing methods:

method for the determination of benzimidazoles: tiabendazol and the sum of benomyl and carbendazim (in 2005-2007) (van Zoonen, 1996),

- method for the determination of the maneb group: maneb, mancozeb, metiram, propineb, thiram, ziram and zineb, the sum is expressed as carbon disulfide (in the years 2005-2009) (Baša Česnik and Gregorčič, 2006)

- $\quad$ multiresidual GC/MS method (in 2005-2009) (Baša Česnik and Gregorčič, 2003; Baša Česnik et al., 2006)

In 2005 the scope was: acephate, aldrin, azinphos-methyl, azoxystrobin, bifenthrin, bromopropylate, bupirimate, captan, carbaryl, carbofuran, chlorothalonil, chlorpropham, chlorpyriphos, chlorpyriphos-methyl, cyhalotrin-lambda, cypermethrin, cyprodinil, DDT, deltamethrin, diazinon, dichlofluanid, dimethoate, diphenylamine, endosulfan, endrin, fenitrothion, fenthion, fludioxonil, folpet, $\mathrm{HCH}$-alpha, heptachlor, heptenophos, imazalil, iprodione, kresoximmethyl, lindane, malathion, mecarbam, metalaxyl, methamidophos, methidathion, myclobutanil, omethoate, oxydemeton-methyl, parathion, permethrin, phorate, phosalone, pirimicarb, pirimiphos-methyl, procymidone, propargite, propyzamide, pyridaphenthion, pyrimethanil, quinalphos, spiroxamine, thiabendazole, tolclofos-methyl, tolylfluanid, triadimefon triazophos, triadimenol and vinclozolin.

In 2006 the scope was extended with the following active substances: cyromazine, penconazole, trifloxystrobin.

In 2007 the scope was extended with the following active substances: boscalid, dichlorvos, fenamidone, quinoxyfen, tebuconazole. Cyromazine was removed.

In 2008 the scope was extended with the following active substances: carboxin, chloridazon, clomazone, cyproconazole, diniconazole, fenbuconazole, indoxacarb, metconazole, methacrifos, metribuzin.

In 2009 the scope was extended with the following active substances: acrinathrin, dazomet, desmethylpirimicarb, dimethachlor, esfenvalerate, fenvalerate, flonicamid, fluquinconazole, HCH-betha, HCH-deltha, hexachlorobenzene, metalaxyl-M, metrafenone, oxadixyl, parathion-methyl, profenofos, quinoclamine, tetraconazole, tetradifon. multiresidual LC/MS/MS method (in 2006-2009) (Bossi et al., 2002; Ortelli et al., 2004; Lehotay et al., 2005).

In 2006 the scope of analyses was: aldicarb, bentazone, cymoxanil, difenoconazole, fenazaquin, fenhexamid, fluroxypyr, imidacloprid, methiocarb, methomyl, phoxim, pymetrozine, spirodiclofen, tebufenozide, thiacloprid, thiamethoxam and zoxamide.

In 2007 the scope was extended with the following active substances: acetamiprid, amidosulfuron, benalaxyl, bitertanol, clofentezine, cyromazine, dimethomorph, epoxiconazole, ethofumesate, famoxadone, fenpropidin, fenpropimorph, fenpyroximate, flufenacet, fluquinconazole, hexythiazox, iprovalicarb, lufenuron, metosulam, pendimethalin, prochloraz, propamocarb, propiconazole, pyridate, spinosad, terbuthylazine, thiophanate-methyl and trichlorfon.

In 2008 the scope was extended with the following active substances: aldicarb sulfon, aldicarb sulfoxid, buprofezin, carbendazim, clopyralid, clothianidin, cycloxydim, desmedipham, flutriafol, foramsulfuron, iodosulfuron-methylsodium, isoxaflutole, linuron, malaoxon, metamitron, metazachlor, methiocarb sulfon, methiocarb sulfoxid, methoxyfenozide, napropamide, phenmedipham, prosulfocarb, prosulfuron, pyraclostrobin, rimsulfuron, tetraconazole, thifensulfuron-methyl, thiodicarb, triasulfuron, trifluralin and triflusulfuron-methyl.

In 2009 the scope was extended with the following active substances: 2,4-D, amitrole, azinphos-ethyl, beflubutamid, benalaxyl M, bromoxynil, carbosulfan, chlortoluron, cyazofamid, demeton-S-methyl sulphone, dichloprop-P, diflufenican, dimethenamid-P, fenarimol, fenoxaprop-P-ethyl, fenoxycarb, fenthion sulfone, fenthion sulfoxide, fipronil, florasulam, fluazifop-P-butyl, fluazinam, fluorochloridone, flusilazole, hexaconazole, isoproturon, mandipropamid, MCPA, monocrotophos, nicosulfuron, oxamyl, paraoxonmethyl, phorate sulfone, phorate sulfoxide, propaquizafop, pyrazophos, teflubenzuron, tribenuron-methyl and trinexapacethyl. Fluquinconazole and tetraconazole were removed.

The trueness of testing methods was verified by recoveries which had to be from $70 \%$ to $120 \%$.

The trueness was additionally verified by participation in the French inter-laboratory proficiency testing scheme BIPEA (Bureau interprofessionnel d'etudes analytiques) and CRL European Proficiency Tests. 


\section{RESULTS AND DISCUSSION}

During the period from 2005 to 2009, 225 IPM samples were analysed. Sample portions below the reporting level (RL), sample portions below or equal to MRLs and sample portions above MRLs are presented in Table 2 .

Table 2. Sample portions of PPP residues for each analysed matrix from 2005 to 2009

\begin{tabular}{|l|l|l|l|}
\hline & Sample portion $<$ RL $(\%)$ & Sample portion $\leq$ MRL $(\%)$ & Sample portion $>$ MRL $(\%)$ \\
\hline apples & 38.7 & 58.6 & 2.7 \\
\hline lettuce & 84.6 & 12.3 & 3.1 \\
\hline potatoes & 98.0 & 2.0 & 0.0 \\
\hline
\end{tabular}

The highest portion of PPP residues exceeding MRLs was found in lettuce (3.1\%). The highest portion of PPP residues found but not exceeded, i.e. 58.6\%, was found in apples. The farmers have to protect apples against rot, mould and insects otherwise they would not be able to grow them. Potatoes were an agricultural product with very little residues found.

Annual results for apples are presented in Table 3.

Table 3. PPP residues in apple samples for the period from 2005 to 2008

\begin{tabular}{|l|l|l|l|}
\hline & Sample portion <RL $(\%)$ & Sample portion $\leq$ MRL $(\%)$ & Sample portion >MRL $(\%)$ \\
\hline 2005 & 0.0 & 93.3 & 6.7 \\
\hline 2006 & 6.7 & 86.7 & 6.7 \\
\hline 2007 & 10.8 & 89.2 & 0.0 \\
\hline 2008 & 27.6 & 72.4 & 0.0 \\
\hline
\end{tabular}

The highest percentage of apple samples with detected but not exceeding PPP residues was found in 2005 (93.3\%) and the lowest in 2008 (72.4\%). The highest MRL exceedances in apple samples were found in 2005 and $2006(6.7 \%)$. The trend observed during the years was exceedances that were no longer determined at the end.

Annual results for lettuce are presented in Table 4.

Table 4. PPP residues in lettuce samples for the period from 2005 to 2009

\begin{tabular}{|l|l|l|l|}
\hline & Sample portion <RL $(\%)$ & Sample portion $\leq$ MRL $(\%)$ & Sample portion >MRL $(\%)$ \\
\hline 2005 & 100.0 & 0.0 & 0.0 \\
\hline 2006 & 91.7 & 8.3 & 0.0 \\
\hline 2007 & 76.5 & 17.6 & 5.9 \\
\hline 2008 & 83.3 & 8.3 & 8.3 \\
\hline 2009 & 75.0 & 25.0 & 0.0 \\
\hline
\end{tabular}

In comparison to apples lettuce is an agricultural product with less PPP residues found. The highest percentage of lettuce samples with detected but not exceeding PPP residues was found in 2009 (25.0\%) and the lowest in $2005(0.0 \%)$. The highest MRL exceedances in lettuce samples were found in 2008 $(8.3 \%)$.

The least PPP residues were found in potato. In 2005, 2007, 2008 and 2009 no residues were found in potato samples. In 2006 the percentage of samples with determined but not exceeding PPP residues was $8.3 \%$.

Multiple residues were found only in apples and lettuce. The results for apples are presented in Figure 1. The highest number of active substances found per one apple sample was 7 in 2006. The trend observed during the years was that the sample portion of samples containing multiple residues in apples decreased from 2005 to 2008 
in spite of the larger number of active substances sought.

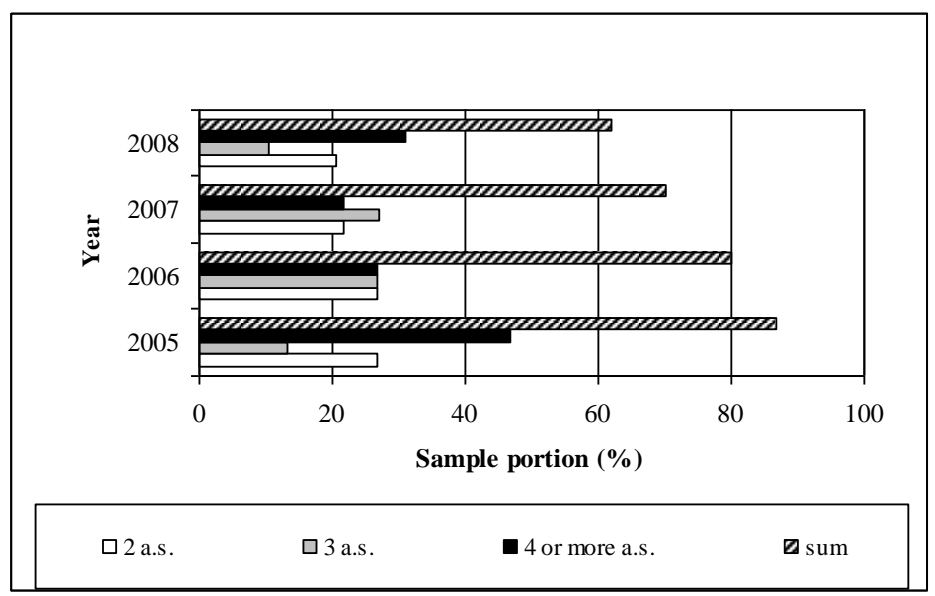

Figure 1.: Multiple residues found in apples from 2001 to 2008

In lettuce, maximum 2 active substances were found per sample: in 2007 in $5.9 \%$ of samples and in 2009 in $16.7 \%$ of samples.
Active substances found in apples are presented in Table 5. The most frequently found active substance was dithiocarbamates (maneb group).

Table 5. Active substances found in apples in the years from 2005 to 2008

\begin{tabular}{|l|l|l|l|l|l|}
\cline { 2 - 6 } \multicolumn{1}{c|}{} & \multicolumn{5}{c|}{ Sample portion (\%) } \\
\hline Active substance & $\mathbf{2 0 0 5}$ & $\mathbf{2 0 0 6}$ & $\mathbf{2 0 0 7}$ & $\mathbf{2 0 0 8}$ & average \\
\hline Acetamiprid & n.a. & n.a. & $\mathbf{2 . 7}$ & $\mathbf{2 4 . 1}$ & $\mathbf{7 . 2}$ \\
\hline Bitertanol & n.a. & n.a. & $\mathbf{5 . 4}$ & n.d. & $\mathbf{1 . 8}$ \\
\hline Boscalid & n.a. & n.a. & $\mathbf{8 . 1}$ & $\mathbf{3 1 . 0}$ & $\mathbf{1 0 . 8}$ \\
\hline Captan & $\mathbf{3 3 . 3}$ & $\mathbf{2 6 . 7}$ & $\mathbf{2 7 . 0}$ & $\mathbf{1 7 . 2}$ & $\mathbf{2 5 . 2}$ \\
\hline Chlorpyrifos & $\mathbf{2 6 . 7}$ & $\mathbf{1 6 . 7}$ & $\mathbf{4 0 . 5}$ & $\mathbf{1 3 . 8}$ & $\mathbf{2 5 . 2}$ \\
\hline Chlorpyrifos-methyl & $\mathbf{6 . 7}$ & n.d. & n.d. & n.d. & $\mathbf{0 . 9}$ \\
\hline Cyprodinil & $\mathbf{1 3 . 3}$ & $\mathbf{3 . 3}$ & $\mathbf{2 . 7}$ & n.d. & $\mathbf{3 . 6}$ \\
\hline Diazinon & $\mathbf{4 0 . 0}$ & $\mathbf{3 0 . 0}$ & $\mathbf{2 4 . 3}$ & n.d. & $\mathbf{2 1 . 6}$ \\
\hline Difenoconazole & n.a. & n.d. & n.d. & $\mathbf{3 . 4}$ & $\mathbf{0 . 9}$ \\
\hline Diphenylamine & n.d. & $\mathbf{3 . 3}$ & n.d. & n.d. & $\mathbf{0 . 9}$ \\
\hline Dithiocarbamates & $\mathbf{9 3 . 3}$ & $\mathbf{7 3 . 3}$ & $\mathbf{3 2 . 4}$ & $\mathbf{3 7 . 9}$ & $\mathbf{5 3 . 2}$ \\
\hline Fenazaquin & n.a. & $\mathbf{3 . 3}$ & n.d. & n.d. & $\mathbf{0 . 9}$ \\
\hline Fluquinconazole & n.a. & n.a. & n.d. & $\mathbf{3 . 4}$ & $\mathbf{0 . 9}$ \\
\hline Folpet & $\mathbf{6 . 7}$ & n.d. & n.d. & n.d. & $\mathbf{0 . 9}$ \\
\hline Lufenuron & n.a. & n.a. & $\mathbf{5 . 4}$ & n.d. & $\mathbf{1 . 8}$ \\
\hline Methoxyfenozide & n.a. & n.a. & n.a. & $\mathbf{1 3 . 8}$ & $\mathbf{3 . 6}$ \\
\hline Phosalone & $\mathbf{2 0 . 0}$ & $\mathbf{4 6 . 7}$ & $\mathbf{4 5 . 9}$ & n.d. & $\mathbf{3 0 . 6}$ \\
\hline Pirimicarb & $\mathbf{6 . 7}$ & n.d. & n.d. & $\mathbf{3 . 4}$ & $\mathbf{1 . 8}$ \\
\hline Pyraclostrobin & n.a. & n.a. & n.a. & $\mathbf{3 1 . 0}$ & $\mathbf{8 . 1}$ \\
\hline Pyrimethanil & n.d. & $\mathbf{2 0 . 0}$ & $\mathbf{1 0 . 8}$ & $\mathbf{1 0 . 3}$ & $\mathbf{1 1 . 7}$ \\
\hline Spirodiclofen & n.a. & $\mathbf{1 6 . 7}$ & $\mathbf{2 1 . 6}$ & $\mathbf{1 0 . 3}$ & $\mathbf{1 4 . 4}$ \\
\hline Tebufenozide & n.a. & $\mathbf{3 . 3}$ & n.d. & $\mathbf{1 0 . 3}$ & $\mathbf{3 . 6}$ \\
\hline Thiacloprid & n.a. & $\mathbf{6 . 7}$ & $\mathbf{2 . 7}$ & $\mathbf{6 . 9}$ & $\mathbf{4 , 5}$ \\
\hline Tolylfluanid & $\mathbf{7 3 . 3}$ & $\mathbf{3 0 . 0}$ & n.d. & n.d. & $\mathbf{1 8 . 0}$ \\
\hline Trifloxystrobin & n.a. & n.a. & $\mathbf{2 . 7}$ & n.d. & $\mathbf{0 . 9}$ \\
\hline n.d means not & & & & \\
\hline & & & & \\
\hline
\end{tabular}

n.a. means not analysed, n.d. means not detected 
PPPs allowed in IPM of apples, which contained active substances from maneb group in years 2006-2008 are presented in Table 6.

Table 6. PPPs allowed in IPM of apple which contained active substances from maneb group from 2006 to 2008

\begin{tabular}{|l|l|l|}
\hline year & PPP & active substance \\
\hline 2006 & Bakreni dithane & mancozeb \\
\hline $2006-2008$ & Dithane Dg neotec & mancozeb \\
\hline $2006-2008$ & Dithane M-45 & mancozeb \\
\hline $2006-2008$ & Kor DG & mancozeb \\
\hline 2006 & Mancozeb 80 WP & mancozeb \\
\hline 2006 & Mazeb & mancozeb \\
\hline $2006-2007$ & Penncozeb 75 DG & mancozeb \\
\hline $2006-2007$ & Penncozeb 80 WP & mancozeb \\
\hline $2006-2008$ & Polyram DF & metiram \\
\hline $2006-2008$ & Thiram 80 WG & thiram \\
\hline $2006-2007$ & Triscobal DG & ziram \\
\hline $2006-2007$ & Ziram 76 WG & ziram \\
\hline
\end{tabular}

Active substances found in lettuce are presented in Table 6. The most frequently found active substance was dithiocarbamates (maneb group).

Table 7. Active substances found in lettuce in the years from 2005 to 2009

\begin{tabular}{|l|l|l|l|l|l|l|}
\cline { 2 - 7 } \multicolumn{1}{c|}{} & \multicolumn{5}{c|}{ Sample portion (\%) } \\
\hline Active substance & $\mathbf{2 0 0 5}$ & $\mathbf{2 0 0 6}$ & $\mathbf{2 0 0 7}$ & $\mathbf{2 0 0 8}$ & $\mathbf{2 0 0 9}$ & average \\
\hline Chlorothalonil & n.d. & n.d. & $\mathbf{5 . 9}$ & n.d. & n.d. & $\mathbf{1 . 5}$ \\
\hline Difenoconazole & n.a. & n.d. & $\mathbf{5 . 9}$ & n.d. & n.d. & $\mathbf{1 . 5}$ \\
\hline Dithiocarbamates & n.d. & $\mathbf{8 . 3}$ & $\mathbf{5 . 9}$ & $\mathbf{8 . 3}$ & $\mathbf{8 . 3}$ & $\mathbf{6 . 2}$ \\
\hline Iprodione & n.d. & n.d. & n.d. & n.d. & $\mathbf{1 6 . 7}$ & $\mathbf{3 . 1}$ \\
\hline Pendimethalin & n.a. & n.a. & n.d. & $\mathbf{8 . 3}$ & n.d. & $\mathbf{1 . 5}$ \\
\hline Propyzamide & n.d. & n.d. & $\mathbf{5 . 9}$ & n.d. & n.d. & $\mathbf{1 . 5}$ \\
\hline Thiamethoxam & n.a. & n.d. & $\mathbf{5 . 9}$ & n.d. & $\mathbf{1 6 . 7}$ & $\mathbf{4 . 6}$ \\
\hline
\end{tabular}

n.a. means not analysed, n.d. means not detected

PPPs allowed in IPM of lettuce, which contained active substances from maneb group in years 2006-2009 are presented in Table 8 .

Table 8. PPPs allowed in IPM of lettuce which contained active substances from maneb group from 2006 to 2009

\begin{tabular}{|l|l|l|}
\hline year & PPP & active substance \\
\hline $2006-2009$ & Aliette flash & metiram \\
\hline $2006-2009$ & Aviso DF & mancozeb \\
\hline $2006-2009$ & Polyram DF & metiram \\
\hline $2006-2009$ & Ridomil gold MZ Pepite & mancozeb \\
\hline
\end{tabular}

In potato only one active substance was found: phosalone in one sample in 2006 (8.3\% in 2006 and average for 2005-2009 2.0\%). Only one PPP with active substance phosalone was allowed in IPM of potatoes in 2006 and 2007: Zolone.
Active substances that exceeded MRLs werethe following: tolylfluanid in 2005 (1 apple sample, residue $=0.73 \mathrm{mgkg}^{-1}, \mathrm{MRL}=0.21 \mathrm{mgkg}^{-1}$ ) and in 2006 (2 apple samples, residue $=0.24$ and $0.26 \mathrm{mgkg}^{-1}$, MRL=0.21 $\mathrm{mgkg}^{-1}$ ), chlorothalonil in 2007 (1 lettuce sample, residue $=0.05 \mathrm{mgkg}^{-1}, \mathrm{MRL}=0.01 \mathrm{mgkg}^{-1}$ ) and 
pendimethalin in 2008 ( 1 lettuce sample, residue $=0.06$ $\left.\mathrm{mgkg}^{-1}, \mathrm{MRL}=0.05 \mathrm{mgkg}^{-1}\right)$.
Considering the non-conformities in IPM (the use of PPP which was not allowed in IPM) we observed only one violation: in 2005 the use of PPP with the active substance folpet on apples (1 sample).

\section{CONCLUSIONS}

The levels of PPP residues in IPM samples of agricultural products in Slovenia in 2005 to 2009 do not give any cause for alarm. We compared our results with those of monitoring of PPP residues in the products of plant origin in 27 European Union Member States (EU MS) and 2 European Free Trade Association (EFTA) States (Norway and Iceland) (http://www.efsa.europa.eu/cs/) in 2007 (apples and lettuce) and in 2008 (potatoes). The type of production in EU is unknown. In EU the MRL exceedances in apples in 2007 match the average exceedances in IPM apples in Slovenia from 2005 to 2008 (2.7\%). In EU, the MRL exceedances in lettuce in 2007 (2.9\%) are slightly lower than the average exceedances in IPM lettuce in Slovenia from 2005 to 2009 (3.1\%). In EU, the MRL exceedances in potatoes in $2008(0.5 \%)$ are higher than the average exceedances in IPM potatoes in Slovenia from 2005 to 2009 (0.0\%).

\section{ACKNOWLEGEMENTS}

The authors would like to thank those who contributed to the work: Ms. Mateja Fortuna and other co-workers at the Central Laboratories of Agricultural Institute of Slovenia. For financial support we express our thanks to the Phytosanitary Administration of the Republic of Slovenia (MAFF) and Inspectorate of the Republic of Slovenia for Agriculture, Forestry and Food (MAFF).

\section{REFERENCES}

Baša Česnik, H. and Gregorčič, A. 2003. Multirezidualna analizna metoda za določevanje ostankov pesticidov $\mathrm{v}$ sadju in zelenjavi. Research Reports Biotechnical Faculty University of Ljubljana, Agriculture, Zootechny, 82, 67180.

Baša Česnik, H. and Gregorčič, A. 2006: Validation of the method for the determination of dithiocarbamates and thiuram disulphide on apple, lettuce, potato, strawberry and tomato matrix. Acta Chim. Slov., 53, 100-104.

Baša Česnik, H., Gregorčič, A., Velikonja Bolta, Š. and Kmecl, V. 2006. Monitoring of pesticide residues in apples, lettuce and potato of the Slovene origin, 2001-04. Food Addit. and Contam., 23, 164-173.

Berrada, H., Fernández, M., Ruiz, M. J., Moltó, J. C. and Mañes, J. 2006. Exposure assessment of fruits contaminated with pesticide residues from Valencia, 2001-03. Food Addit. and Contam., 23, 674-682.

Bossi, R., Vejrup, K. V., Mogensen, B. B. and Asman, A. H. 2002. Analysis of polar pesticides in rainwater in Denmark by liquid chromatography-tandem mass spectrometry. J. Chromatogr. A, 957, 27-36.

Čajka, T.and Hajšlová, J. 2004. Gas chromatography-highresolution time-of-flight mass spectrometry in pesticide residue analysis: advantages and limitations. $J$. Chromatogr. A, 1058, 251-261.

Danis, T. G., Karagiozoglou, D. T., Tsakiris, I. N., Alegakis, A. K., and Tsatsakis, A. M. 2011. Evaluation of pesticide residues in Greek peaches during 2002-2007 after the implementation of integrated crop management. Food Chem. 126, 97-103.

Díez, C., Traag, W.A., Zommer, P.; Marinero, P. and Atienza, J. 2006. Comparison of an acetonitrile extraction/partitioning and »dispersive solid-phase extraction « method with classical multi-residue methods for the extraction of herbicide residues in barley samples. J. Chromatogr. A, 1131, 11-23.

Ferrer, I., García-Reyes, J. F., Mezcua, M., Thurman, E. M. and Fernández-Alba, A. R. 2005. Multi-residue pesticide analysis in fruits and vegetables by liquid chromatography-time-of-flight mass spectrometry. $J$. Chromatogr. A, 1082, 81-90.

Lehotay, S. J., de Kok, A., Hiemstra, M. and Bodengraven, P. 2005. Validation of a Fast and Easy Method for the Determination of Residues from 229 Pesticides in Fruits and Vegetables Using Gas and Liquid Chromatography and Mass Spectrometric Detection. J.AOAC Int.., 88, 595-614.

Lehotay, S. J. 2007. Determination of pesticide residues in foods by acetonitrile extraction and partitioning with magnesium sulfate: collaborative study. J. AOAC Int., 90, 485-520.

Maštovská, K., Lehotay, S. J. and Anastassiades, M. 2005. Combination of analyte protectants to overcome matrix effects in routine GC analysis of pesticide residues in food matrixes. Anal. Chem., 77, 8129-8137. 
Oliva, J., Navarro, S., Navarro, G., Cámara, M. A. and Barba, A. 1999. Integrated control of grape berry moth (Lobesia botrana), powdery mildew (Unicula necator), downy mildew (Plasmopara viticola) and grapevine sour rot (Acetobacter spp.). Crop. Prot. 18, 581-587.

Ortelli, D., Edder, P. and Corvi, C. 2004. Multiresidue analysis of 74 pesticides in fruits and vegetables by liquid chromatography-electrospray-tandem spectrometry. Anal. Chim. Acta, 520, pp. 33-45.

Peshin, R., Dhawan, A. K. 2009. Integrated Pest Management: Innovation-Development Process. Springer Science+Business Media B.V., 631-666.

Pizzutti, I. R., Vreuls, R. J. J., de Kok, A., Roehrs, R., Martel, S., Friggi, C. A. and Zanella, R. 2009. Design of a compressed air modulator to be used in comprehensive multidimensional gas chromatography and its application in the determination of pesticide residues in grapes. $J$. Chromatogr. A, 1216, 3305-3311.

RS (2004a). Law on Plant Protection Products, Official Gazette of the Republic of Slovenia No. 98, 09.09.2004, pp. 11885-11899.

RS (2004b). Regulation on Pesticide Residues in or on Foodstuffs in Agricultural Products, Official Gazette of the Republic of Slovenia No. 84, 30.07.2004, pp. 1021010226.

RS (2007a). Law on Plant Protection Products, Official Gazette of the Republic of Slovenia No. 35, 18.04.2007, pp. 5017-5031.

RS (2007b). Regulation on changes and completion of Regulation on Pesticide Residues in or on Foodstuffs and Agricultural Products No. 108, 27.11.2007, pp. 14834.

RS (2009). Regulation on the implementation of EC Parliament and EC Council Regulation on limit values of pesticide residues in or on the food or forage of plant and animal origin, Official Gazette of the Republic of Slovenia No. 16, 27.02.2009, pp. 2081-2082.

Sharif, Z., Che Man, Y. B., Hamid, N. S. A. H. and Keat, C. C. 2006. Determination of organochlorine and pyrethroid pesticides in fruit and vegetables using solid phase extraction clean-up cartridges. J. Chromatogr. A, 1127, 254-261.

Stan, H.-J. and Linkerhägner, M. 1996. Pesticide residue analysis in foodstuffs applying capillary gas chromatography with atomic emission detection State-ofthe-art use of modified multimethod S19 of the Deutsche Forschungsgemeinschaft and automated large-volume injection with programmed-temperature vaporization and solvent venting. J. Chromatogr. A, 750, 369-390.

Turgut, C., Ornek, H. and Cutright, T. J. 2011. Determination of pesticide residues in Turkey's table grapes: the effect of integrated pest management, organic farming, and conventional farming. Environ. Monit. Assess.173, 315323.

Vasileiadis, V. P., Sattin, M., Otto, S., Veres, A., Pálinkás, Z., Ban, R., Pons, X., Kudsk, P., van der Weide, R., Czembor, E., Moonen, A. C. and Kiss, J. 2011. Crop protection in European maize-based cropping systems: Current practices and recomendations for innovative integrated Pest Management. Agr. Syst., article in press.

Van Zoonen, P. 1996. Benomyl/Carbendazim/Thiabendazole, Analytical Methods for Pesticide residues in Foodstuffs, van Zoonen, P. (Ed.), General Inspectorate for Health Protection Ministry of public Health, Welfare and Sport Netherlands, 2. Part, p. 1-4, Bilthoven: Rijksinstituut voor Volkgezondheid en Milieu (RIVM). 